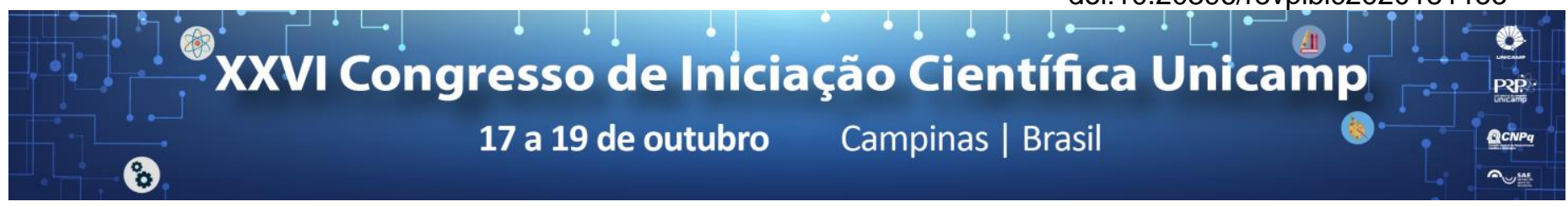

\title{
A questão dos agrotóxicos no Brasil e o Projeto de Lei $n^{\circ}$ 6.299/2002: um estudo da controvérsia
}

\section{Priscila Morgon Arruda, Roberto Donato da Silva Junior}

\begin{abstract}
Resumo
O estudo da controvérsia no campo dos estudos sociais da ciência evidencia a relação existente entre os conteúdos de ordem social e a produção científica. Por meio da análise dos documentos relacionados à tramitação do Projeto de Lei no 6.299 de 2002 para estudar a questão dos agrotóxicos no Brasil, com base nos Estudos Sociais da Ciência, o objetivo é compreender a influência do conteúdo social e da ciência no processo de tomada de decisão política, as formas de legitimação do conhecimento científico acerca do tema e as intenções que se manifestam através do discurso dos atores envolvidos.
\end{abstract}

Palavras-chave: Agrotóxicos, Controvérsia científica, Estudos Sociais da Ciência.

\section{Introdução}

O agrotóxico é um composto utilizado para eliminar determinados seres vivos em um cultivo agrícola e o referencial legal mais importante no Brasil que regulamenta esta questão é a Lei no 7.802 de $1989^{1}$, que disciplina a produção, comercialização e uso de agrotóxicos. Nesse contexto, são elaborados projetos de lei como tentativa de propor alterações na legislação para atualizar o conteúdo de acordo com as necessidades do cenário do desenvolvimento agrário no Brasil. O Projeto de Lei (PL) n 6.299/2002, de autoria de Blairo Maggi, prevê a modificação dos artigos $3^{\circ}$ e $9^{\circ}$ da Lei $n^{\circ}$ 7.802/1989.

A questão dos agrotóxicos representa uma controvérsia científica pois constitui uma discordância ainda aberta entre a comunidade científica e é no processo de tramitação que os cientistas são incluídos nas discussões a partir de requerimentos para participarem de audiências públicas e seminários.

Sendo assim, com base nos estudos sociais da ciência, o objetivo geral da pesquisa é investigar a controvérsia referente ao tema dos agrotóxicos no Brasil a partir de um recorte analítico. Para tanto, foram analisados os documentos e uma audiência pública da tramitação do PL 6.299/2002, com foco no conteúdo e na identificação da mobilização dos atores científicos no debate político. A construção deste caminho serve como base para analisar como se sucedeu a controvérsia científica no âmbito da construção do projeto de lei.

\section{Resultados e Discussão}

O Projeto de Lei $n^{\circ} 6.299 / 002$ altera os artigos $3^{\circ}$ e $9^{\circ}$ da Lei dos Agrotóxicos. No artigo $3^{\circ}$, o parágrafo adicionado diz respeito ao registro do princípio ativo do agrotóxico e no artigo 9ำ inclui no inciso I uma ampliação dentre as competências da União, diminuindo as funções dos estados e municípios ${ }^{2}$.

A primeira alteração tem como objetivo simplificar o processo de registro do agrotóxico e desconsidera que o ingrediente ativo não é o único constituinte que influencia na interação do produto com o meio ambiente. A segunda alteração exclui as competências de estados e municípios na definição de procedimentos que envolvem os agrotóxicos. Porém, são estes entes que conhecem as especificidades do local.

São dois os conceitos norteadores da análise introduzidos por Harry Collins. Core sets define a classe formada pelos cientistas envolvidos nos experimentos e teorizações relevantes para a controvérsia científica ou o debate e o Problema da Extensão trata do limite de dissolução das fronteiras entre os experts e o público leigo a fim de ampliar o âmbito de decisão em questões técnicas, sendo que estas constituem segmentos nos quais a ciência e a tecnologia se mesclam com o domínio político por serem relevantes ao público.

A única audiência pública realizada no âmbito do referido projeto de lei conta com a participação de Walter Steenbock (Analista Ambiental do ICMBio), Ana Maria Andrade (Antropóloga do ISA), Rodrigo Justos de Brito (Presidente da Confederação Nacional da Agricultura), Fabricio Rosa (Diretor Executivo da Aprosoja Associação Brasileira dos Produtores de Soja) e Ernst Götsch (pesquisador e precursor do movimento da agrofloresta).

\section{Conclusões}

$\mathrm{Na}$ inclusão de cientistas e especialistas da área, há claramente uma cisão entre as opiniões. De um lado se posicionam aqueles que defendem uma agricultura mais sustentável e, do outro, o agronegócio. O que se verifica na prática é a força da bancada ruralista em defesa do agronegócio, com discurso desenvolvimentista, voltado ao aumento da produção agrícola com base em investimentos na tecnologia. Os órgãos de saúde e do meio ambiente alertam todos os malefícios causados pela aplicação de agrotóxicos, entretanto não conseguem apoio suficiente.

\section{Agradecimentos}

Agradeço ao Roberto Donato da Silva Júnior, orientador deste projeto, pelo apoio e direcionamento. Agradeço também ao $\mathrm{PIBIC} / \mathrm{CNPq}$ pelo financiamento desta pesquisa.

\footnotetext{
1 BRASIL. Lei no 7.802, de 11 de julho de 1989. Dispõe sobre a pesquisa, a experimentação, a produção, a embalagem e rotulagem, o transporte, o armazenamento, a comercialização, a propaganda comercial, a utilização, a importação, a exportação, o destino final dos resíduos e embalagens, o registro, a classificação, o controle, a inspeção e a fiscalização de agrotóxicos, seus componentes e afins, e dá outras providências. Diário Oficial [da República Federativa do Brasil], Brasília, DF
}

2 BRASIL. Projeto de Lei nํ 6.299-A, de 2002 (do Senado Federal) PLS n. 526/1999. Altera os arts $3^{\circ}$ e $9^{\circ}$ da Lei $n^{\circ} 7.802$, de 11 de julho de 1989. Diário Oficial [da República Federativa do Brasil], Brasília, DF 